By RAYNARD C. SWANK

\title{
University of Oregon Statutes and Supplementary Library Policies Relating to the Professional Library Staff
}

\section{Dr. Swank, director, Stanford University}

Libraries, wrote this article while librarian of the University of Oregon.

$\mathrm{T}$

HE FOLLOWING statement of selected personnel policies, which are now in effect at the University of Oregon Library, consists of: (a) excerpts from the Administrative Code ${ }^{1}$ of the Oregon State System of Higher Education, and (b) supplementary interpretations affecting the professional library staff. The quotations from the Administrative Code apply generally to the academic staffs of the University of Oregon, Oregon State College, and other institutions in the state system, within which professional librarians have held academic ranks since $\mathbf{1} 932$.

\section{Tenure}

Administrative Code, K-8a. Academic Staff. Members of the academic staff below the rank of assistant professor are generally appointed on one-year tenure unless in individual cases there is a definite understanding to the contrary. On recommendation of the executive head of the institution and the chancellor and the approval of the board, members of the academic staff of the rank of assistant professor or above may be placed on indefinite tenure.

\footnotetext{
1 Oregon State Board of Higher Education. $A d$. price of about $\$ 40$.
}

\section{Working Hours}

Administrative Code, K-9a. Academic. Because of the varied nature of the work, no attempt is made to define the exact number of working hours of administrative, instructional, research, or extension workers. All such staff members are expected to give the institution their undivided efforts, free from outside interests that interfere with their ability to render the institution maximum service. Determination of time of service is the responsibility of the executive head of the institution.

Library policy. a. According to the general regulation applicable to the academic staff, no definite working hours are prescribed for the professional members of the library staff, the measure of their service being the degree to which they fulfill the responsibilities of their individual jobs and devote their maximum efforts to the advancement of the library program, broadly conceived.

b. Responsibility for determining the adequacy of services rendered by staff members rests immediately with the department heads.

c. It is recognized that the nature of the work in some departments necessitates intradepartmental working schedules of varying lengths and degrees of exactness, for example, at service points and where the duties of several staff members are interdependent. Intra-departmental schedules, where necessary for adequate service, will be arranged by the department heads. It is expected that regularly recurring schedules will be kept as short as possible in order to allow maximum freedom to staff members in the organization of other phases of their jobs. 
d. Attendance at faculty, committee, and other meetings of an official character, is interpreted as a responsibility of staff members in the performance of their regular jobs.

\section{Vacations}

Administrative Code, K-Io. Vacation privilege is defined to mean absence from duty for the purpose of recreation and rest for a limited period during which regular compensation is received. Vacation privilege is not cumulative from year to year. Vacation privilege is not open to employees not serving for twelve months of the year.

Administrative Code, K-roa. Academic Staff. Staff members in the academic classification who are appointed on a twelve-months basis are eligible for one month's vacation with pay after one year's service.

Library policy. For all staff members, the vacation month is interpreted as twenty-seven working days and is computed on the basis of a six-day week. Institutional holidays are not regarded as working days.

\section{Sabbatical Leave}

Administrative Code, K-12. After six years of continuous service as a regular full-time member of the staff of any of the institutions of higher learning under the control of the state board of higher education, a staff member may be granted leave of absence not to exceed one year, better to fit himself for service to his institution and the state. Professorial rank is defined as that of assistant professor or above. (See Administrative Code for further details.)

\section{Arrangements in Case of Illness}

Administrative Code, K-13. Arrangements to care for the work of a staff member incapacitated by illness over a period longer than one month must have the approval of the executive head of the institution.

Library policy. No definite period of sick leave is specified.

a. Arrangements to care for the work of a staff member incapacitated by illness over a period longer than two weeks at one time must have the approval of the librarian.

b. Recurring brief illnesses, including dental and medical appointments, must be reported to the librarian by the department head when, in their cumulative effect, they begin to interfere with adequate service. Adjustments will be made on the merits of each case.

\section{Privileges of Staff Members}

Administrative Code, K-r6a. Academic Work. Full-time staff members may have the privilege of registering for class work on the following conditions: Staff members on a regular salary basis, other than graduate assistants, scholars, and fellows, must make application for the privilege of carrying work for credit, such application to be approved by the department head and the dean, and substituted for approval to the executive head of the institution before being filed in the registrar's office. In general, full-time staff members shall not carry work involving more than three term hours of credit; five term hours shall be the maximum. Requests may be in the form of a letter and should make clear the subjects and credits for which registration is requested. It is assumed that the regular duties of the staff member will not be interfered with.

Administrative Code, K-I6b. Auditing. "Auditor" privileges are accorded staff members under the same general procedures as provided above (no special application to the executive office). Auditors are not expected to participate in the class discussions, and their presence should in no way interfere with the class program.

Library policy. a. Auditors are expected to report their activities to the department head, who will relay the information to the librarian for the record.

b. Every reasonable effort should be made to adjust working schedules in such a way as to accommodate staff members who wish to attend classes, whether or not for credit, which will contribute to better performance on the job.

\section{Holidays}

Administrative Code, K-17. The following are institutional holidays: New Year's Day, Memorial Day, July Fourth, Labor Day, Thanksgiving Day, Christmas Day. On these days all employees compensated on an annual or monthly basis are excused from regula1 institutional work, except where their duties (Continued on page 45) 
chusetts and Connecticut. It appears that the smaller the library the smaller the resources which can be expected for university development, as well as other governmental services.

\section{Summary}

The following points emerge regarding interstate cooperation in higher education with special reference to the state university libraries which might be involved:

I. The idea of regional cooperation in advanced levels of higher education, while strongly motivated by the desire to continue the practice of racial segregation, has gone beyond that objective. Its application to the general problem of providing university facilities which are not available in large areas of the country has been advocated and is permissible under the compact of February 8, 1948, between fifteen Southern states.

2. Figures for 1944 , with estimates to 1948 , show that about one-half the state university libraries of the country have less than 300,000 volumes. A considerable part of this group, on the basis of a sampling of eleven institutions, offers work up to the Ph.D. degree, and supports one or more graduate professional schools. It is obvious that for existing programs and for expansion these institutions are seriously handicapped with regard to library resources.

3. Enrolments are expected to remain at levels substantially higher than those of prewar years. On a short-term basis a larger proportion of upperclassmen and graduate students can be expected; on a long-term basis the predictions are more doubtful, though the higher general enrolment levels will mean increased demands for all reading materials. This pressure will be felt with special force in those collecting areas which are, and usually have been, given less attention in smaller universities. Such areas include the high-level research literature in a number of subject fields.

4. The twenty-three below-median libraries can be grouped into coherent regional divisions. The Southern states subscribing to the compact of February 8 fall into several groups rather than one. The remaining states, with the addition of a few possessing libraries just above the median size, can be similarly aligned. The institutions which support the libraries are likely to be those which also require extensive additions to their research facilities, and therefore have most to gain from cooperation with others in the same situation.

\section{Microprint Reader}

\section{(Continued from page 38 )}

cost between film and paper is insignificant except in the case of mass reproduction.

Whether in the end film or Microcards will prove more suitable for library use will depend not only on their relative degree of satisfactory performance and the rela- tive cost of production, maintenance, and use, but also upon the manner of distribution of microreproductions and reading machines, and, last but not least, upon their acceptance by the library user as substitutes for the printed page.

\section{Oregon Statutes \\ (Continued from page 40)}

are of such character that release is not practicable, in which case the same amount of time may be allowed at another date. Student recesses in addition to the days above named do not constitute institutional holidays.

\section{Professional Activities}

Administrative Code, K-19. No full-time employee in the Oregon State System of Higher Education or of any of the institutions thereof shall engage in any outside activity which substantially interferes with his regular duties. Prior to acceptance of any employment involving time or honorarium, the individual concerned shall secure the approval of the executive head of the institution. 